\title{
Genetic linkage map of willow (Salix leucopitheciaxS.erioclada L) based on AFLP and SSR markers
}

\author{
Jian-Jun Hu*, Jin-Hui Lv, Meng-Zhu Lu \\ From IUFRO Tree Biotechnology Conference 2011: From Genomes to Integration and Delivery \\ Arraial d'Ajuda, Bahia, Brazil. 26 June - 2 July 2011
}

Due to its fast growth rate and little nursery requirements, willow is largely planted as short rotation coppice species for bioenergy resources in temperate regions. Willow coppices can be easily established by vegetative propagation of cuttings and can remain productive for up to 25 years. In China, diploid species $S$. leucopithecia and S. erioclada L. are two promising willow species that can be used for high biomass plantation. In order to further improve the biomass yield and resistance to drought and pests, we tried to create a genetic map to assist willow breeding. $560 \mathrm{~F}_{1}$ individuals from a cross between $S$. leucopithecia x $S$. erioclada L were used to generate a willow genetic map using AFLP and SSR markers.

Both Populus and Salix are members of the Salicaceae. They share genomic homologues with high similarity and many common biological traits. As a model species for biological studies in trees,Populus has considerable genetic and genomic resources, which could provide cues for willow study. Five hundred pairs of SSR primers were selected from Populus database for willow analysis; 88 of them successfully generated polymorphic loci between S. leucopithecia x S. erioclada L. In addition, 24 pairs of AFLP primers also succeeded in detecting polymorphic fragments from $F_{1}$ individuals.

We selected 243 individuals to construct a framework linkage maps of parents using a two-way pseudo-testcross strategy. The linkage map of S.erioclada L contains 98 loci, organized in 15 linkage groups with total map distances between $76.7 \mathrm{cM}$ and $209.5 \mathrm{cM}$. The average map distance between markers is $18.6 \mathrm{cM}$ and the total genetic distance is about $1,810 \mathrm{cM}$, covering

\footnotetext{
* Correspondence: huij@caf.ac.cn

Research Institute of Forestry, Chinese Academy of Forestry, Beijing 100091, PR China
}

(c) 2011 Hu et al; licensee BioMed Central Ltd. This is an open access article distributed under the terms of the Creative Commons Attribution License (http://creativecommons.org/licenses/by/2.0), which permits unrestricted use, distribution, and reproduction in any medium, provided the original work is properly cited.
Cite this article as: Hu et al.: Genetic linkage map of willow (Salix
(10.1186/1753-6561-5-P29 leucopithecia $\times$ S.erioclada $L$ ) based on AFLP and SSR markers. BMC Proceedings 2011 5(Suppl 7):P29.
Submit your next manuscript to BioMed Central and take full advantage of:

- Convenient online submission

- Thorough peer review

- No space constraints or color figure charges

- Immediate publication on acceptance

- Inclusion in PubMed, CAS, Scopus and Google Scholar

- Research which is freely available for redistribution Submit your manuscript at
www.biomedcentral.com/submit C Biomed Central 